\title{
The Impact of Remuneration and Training and Development on Organizational Commitment
}

\author{
Ashfaq Ahmad ${ }^{1}$, Syed Mir Muhammad Shah ${ }^{2 *}$, Palwasha Bibi ${ }^{1}$, Syed Muzafar \\ Hussain Shah ${ }^{1}$
}

\begin{abstract}
This study objects to explore the effect of remuneration and training and development (T\&D) on organizational commitment (OC). The emphasis of the current study was to clarify a university through remuneration and T\&D can accomplish to retain and to be committed with their academic staff. The current study also highlights that remuneration and $T \& D$ are best practices which can be adopted and applied even after changes in environment, practices and technology. The study used a cross-sectional and quantitative mail survey approach by getting responses from 346 by using stratified random sampling. The result revealed that remuneration has a major impact over OC. The result also showed that $\mathrm{T} \& \mathrm{D}$ is a vital factor for the $\mathrm{OC}$ in public higher education institutions (HEIs). Theoretically, the current study has contributed towards a body of knowledge concerning to organizational commitment under the domain of social exchange theory (SET). Practically, by employing the current study outcomes HR managers, particularly of the universities will be able to pay their attention to some specific factors such as remuneration and T\&D to enhance employee retention. Finally, recommendations and limitation with reference to the current study and sector are presented. This study aims to be beneficial for the HR managers at HEIs and the policy makers.
\end{abstract}

Keywords: Remuneration, Training and Development, Organizational Commitment, Higher Education Institutions.

\section{Introduction}

Higher education institution plays an imperative role in to strengthen the entire system of education and the economic development (Mangi, Soomro, Ghumro, Abidi, \& Jalbani, 2011). HEIs serve as an integral part in the progress of any country. Likewise, in Pakistan it also plays significant role in her progress and development (Rasheed, Aslam, \& Sarwar, 2010). For any higher education institutes, the main asset for its success is the commitment of its academic staff (Omar, Mohamed Anuar, Majid, Halim, \& Johari, 2012). According to Chughtai and Zafar (2006) highly committed academic staff plays a central role in the accomplishment of any tertiary institution. However, the one the most critical issues in the higher education institutes is academic staff

https://doi.org/10.30537/sijmb.v4i2.109

${ }^{1}$ College of Business, Universiti Utara, Malaysia

2 Department of Business Administration, Sukkur IBA University

* Corresponding Author: syedmir@iba-suk.edu.pk 
commitment (Khan, Nawaz, \& Khan, 2013). Likewise, Shaheen, Sajid, and Batool (2013) also mentioned in their study that due to accessibility of more choices, stakeholders are now complaining about the academic staff commitment and devotion.

Generally, factors that influence organizational commitment in Pakistan have been discussed and examined empirically by several scholars. However, the disagreement arises in the empirical findings from each study due to different human resource management (HRM) practices under study in varying context and sectors and its effect on organizational commitment, but still there is a dire need to uncover and investigate further (Paul \& Anantharaman, 2004).

Thus, the current study is focused on OC of academic staff in public sector universities in Pakistan. Enhancing the $\mathrm{OC}$ among the academicians is very important. Past researchers highlighted the importance of the OC that well motivated and committed employees perform well and stay loyal. It is indicated from literature review that there is a dire need to investigate further in the area of OC in Pakistan, especially in public HEIs. Therefore, the present study aims to investigate the relationship in between remuneration and training and development and organizational commitment.

\subsection{Problem definition}

Higher education institute is one of the growing sectors in Pakistan and it contributes significantly in the economic development as well as social development of country. Most of the researchers have studied remuneration and T\&D in various industries, but these variables have limitedly studied in education sector of Pakistan. In Addition, most of studies have been carried in western and advanced countries on HRM practices (i.e., remuneration and T\&D) and organizational commitment. However, in the context of developing countries like Pakistan a very few studies have been conducted, particularly in the higher education sector (Sial, Jilani, Imran, \& Zaheer, 2011). Moreover, most of the previous studies have been done on HRM practices and organizational level performance (Becker \& Gerhart, 1996; Delery \& Doty, 1996; Huselid, 1995). But very few studies have highlighted that how remuneration and T\&D can facilitate individual employee commitment (Allen, Shore, \& Griffeth, 2003). There is a need to investigate these variables and their effect on the OC, specifically in HEIs of Pakistan.

Furthermore, most of the HEIs do not have a professional HR department and managers. Mostly managers of the HEIs are unaware of the fact that managers need to retain their academic staff through remuneration and T\&D. This study will assist the HR department and manages in the HEIs sector in Pakistan to develop their policy to increase employee retention and employee commitment. In view of this literature gap, the present study is aimed at examining the issue by investigating the relationship between remuneration, $\mathrm{T} \& \mathrm{D}$ and organizational commitment with a specific focus on the academic staff of HEIs. 


\subsection{Remuneration}

Compensation refers to the pay that staff members receive from the organization for their rendered services (Mondy, 2008). Remuneration has frequently been discussed in the literature. The monthly salaries to be paid to the faculty have been operationalized as compensation in the present study. Compensation is one of the essential contractual agreements between the employees and organization (Chew \& Chan, 2008). Researchers have consistently explained that compensation plays important role in attracting qualified potential employees and increases commitment of current employees. Well committed and devoted academic staff is really a strategic phenomenon (A. Ahmad, Majid, A. H. A., \& Zin, M. L. M., 2015). Sometimes organization offers attractive compensation to retain skilful workforce (GouldWilliams, 1999; Nazir, Shah, \& Zaman, 2012; Parker \& Wright, 2001). Compensation is a key aspect of workforce motivation (Nazir, Shah, \& Zaman, 2014).

Attractive remuneration packages are a key factor of retention as it fulfills the financial and material desire. When employees feel that they are receiving sufficient compensation, they stay longer in the organization (A. Ahmad, 2016; Bibi, 2016). Numerous scholars Bamberger and Meshoulam (2000) and MacDuffie (1995) highlighted that remuneration system plays an important role to retain the employee and enhance their performance level. Similarly, A. Ahmad (2016) and Khan et al. (2013) found that there is an important relationship between remuneration and organizational commitment. Similarly, (Bibi (2016); Bibi, Pangil, Johari, and Ahmad (2017)), also highlighted that compensation is competitive advantage for organizations to improve performance and ability to increasing the commitment level of employees. This implies that when employees receive an attractive compensation package, they feel that organization cares about them, this notion is also supported by SET theory (Blau, 1964). Likewise, R. Saeed et al. (2013) also concluded that the association between remuneration and $\mathrm{OC}$ is imperative. Keeping in view the evidences found in the literature of the past studies it is clear that the remuneration may potentially contribute to $\mathrm{OC}$, hence proposed hypothesis is as under:

H1: There is a significant and positive relationship between remuneration and organizational commitment.

\subsection{Training \& development and organizational commitment}

Training and development refers to the degree of professional training received by academic staff from their institutes in order to enhance their skills (Delery \& Doty, 1996).

T\&D was operationalized as formal training programs provided by public sector HEIs in Pakistan in order to improve the skills of academic staff that are needed to perform their jobs. T\&D is a very vital aspect of workforce motivation and to improve their knowledge (A. Ahmad, Bibi. P., Khalid, M.M., \& Aziz, 2017; Bibi et al., 2017). 
Training is a costly activity yet organizations pay special attention to T\&D programs to enhance the employee commitment level (Elangovan \& Karakowsky, 1999; Lamba \& Choudhary, 2013).

Likewise, training plays a significant role in the current competitive environment and also benefits the employees to achieve their organizational goals (Schuler \& MacMillan, 1984; Tsai \& Tai, 2003). Furthermore, Chung (2013) probed the correlation between commitment and training in the context of Korea. The outcome of the study showed significant relationship between training and commitment (Chung, 2013). Similarly, Robinson (2013) explored the relationship between the training and organizational commitment. The study revealed significant relationship between training and commitment. Similarly, M. M. Saeed and Asghar (2012) explained that trained employees are more competent and perform their job better than untrained employees.

Alternatively, the finding of a study conducted by Lee, Nam, Park, and Ah Lee (2006) claimed negative relationship between $T \& D$ and organizational commitment. The literature also showed that further research is required to investigate the association between training and organizational commitment in the context of developing world Riaz, Idrees, and Imran (2013), mainly in the sector of public tertiary institutions.

Therefore, it can be inferred that training programs play major role in enhancing the commitment level of academic staff. Thus, this study hypothesizes that:

H2: There is significant and positive relationship between training and development and organizational commitment.

\subsection{Research framework}

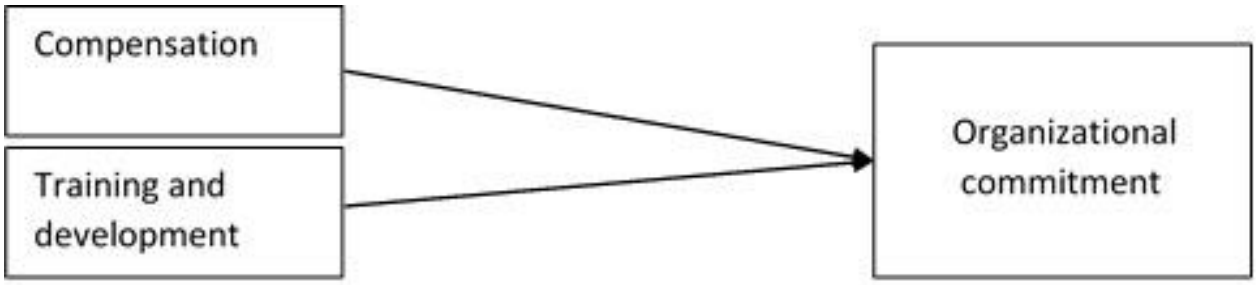

Figure 1: Research Framework

\section{Methodology}

\subsection{Participants and Respondents' Profile}

Research design considered is a main phase toward the accomplishment of a research objective (Bush, 2003). To meet the objectives of the research, statistical, cross sectional and descriptive research method was employed. Survey was carried out through distributions of questionnaires to the respondents. Based on the hypotheses and objectives 
of the research, a questionnaire is considered to be a suitable instrument to collect data in the study.

The total population for this study is 3500. Considering a response rate of 70\%, 500 questionnaires were distributed using stratified random sampling among academic staff of certain public HEIs of Pakistan. Stratified random sampling is considered most suitable method for the current study. The survey involved measures of remuneration, T\&D and OC. Total 346 questionnaires were collected from academic staff. Out of the respondents, $75 \%$ were males; majority of the respondents are lecturers (64\%) and assistant professors (30\%). Most of the respondents hold Ms degree (66\%) and $28 \%$ of the respondent hold postgraduate degree, while only $6 \%$ of the respondents hold degree of doctorate. $64 \%$ of the respondents were married while $36 \%$ were unmarried.

\subsection{Measurement}

Organizational commitment - OC is operationalized as the willingness of the academic staff to accept and agree with university values and goals (Malik, Nawab, Naeem, \& Danish, 2010). To measured OC 9 items short version were used by (Mowday, Steers, \& Porter, 1979).

Remuneration - Remuneration is operationalized as pay which academic staff receive as part of services rendered to university (Teclemichael Tessema \& Soeters, 2006). 5 items of Teclemichael Tessema and Soeters (2006) were used to measure Remuneration.

Training and development $-\mathrm{T} \& \mathrm{D}$ can be defined as how often academic staff received training for the improvement of their skills while working in public sector universities (Delery \& Doty, 1996). 4 items were used to measure T\&D (Delery \& Doty, 1996).

\section{Result}

The current study employed PLS path modelling Wold (1974) to examine the theoretical model. The PLS path modelling is seen as the most appropriate technique in this work. PLS path modelling is similar to conventional regression technique, it delivers the advantage of calculating the relationships between constructs (structural model) and relationships between indicators and their corresponding latent constructs (measurement model) simultaneously (Chin, Marcolin, \& Newsted, 2003; Duarte \& Raposo, 2010). Moreover, it has been proposed that if research is prediction-oriented or an extension of an existing theory, PLS path modelling should be employed (Joe F Hair, Ringle, \& Sarstedt, 2011).

\subsection{Convergent validity}

The researcher examined the convergent validity to conform that factor loadings, average variance extracted (AVE) and composite reliability (CR) meet the threshold value. Furthermore, Table 1 shows that the CR for all the constructs is above 0.7 
Ashfaq Ahmad (et al.) / The Impact of Remuneration and Training and Development on Organizational

threshold as recommended by (Joseph F Hair, Black, Babin, Anderson, \& Tatham, 1998). The AVE was exceeding then 0.5 and the factor loadings for all items were above 0.5 as recommended by (Joseph F Hair et al., 1998).

Table 1: Average variance extracted, factor loading and Composite reliability of Latent variables

\begin{tabular}{|c|c|c|c|c|}
\hline CONSTRUCT & ITEM & LOADING & $\begin{array}{l}\text { Composite } \\
\text { Reliability } \\
\end{array}$ & AVE \\
\hline \multirow[t]{9}{*}{ Organizational commitment } & OC1 & 0.679 & 0.907 & 0.522 \\
\hline & OC2 & 0.613 & & \\
\hline & OC3 & 0.697 & & \\
\hline & OC4 & 0.712 & & \\
\hline & OC5 & 0.673 & & \\
\hline & OC6 & 0.776 & & \\
\hline & OC7 & 0.826 & & \\
\hline & OC8 & 0.758 & & \\
\hline & OC9 & 0.749 & & \\
\hline \multirow[t]{5}{*}{ Remuneration } & REM1 & 0.764 & 0.924 & 0.711 \\
\hline & REM2 & 0.826 & & \\
\hline & REM3 & 0.906 & & \\
\hline & REM4 & 0.893 & & \\
\hline & REM5 & 0.817 & & \\
\hline \multirow[t]{4}{*}{ Training and development } & TD1 & 0.815 & 0.909 & 0.715 \\
\hline & TD2 & 0.886 & & \\
\hline & TD3 & 0.896 & & \\
\hline & TD4 & 0.779 & & \\
\hline
\end{tabular}

\subsection{Discriminant Validity}

The discriminant validity in this study is accomplished by analysing the correlation among the latent construct with the square root of AVE (Duarte \& Raposo, 2010). Similarly, discriminant validity is also realized by comparing the indicator loading with the cross loading (Joseph F Hair, Ringle, \& Sarstedt, 2013).

Table 2: The Square Root of AVE and the correlations of the latent variables

\begin{tabular}{cccc}
\hline & OC & REM & TD \\
\hline OC & $\mathbf{0 . 7 2 3}$ & & \\
REM & 0.170 & $\mathbf{0 . 8 4 3}$ & \\
TD & 0.590 & 0.129 & $\mathbf{0 . 8 4 6}$ \\
\hline
\end{tabular}

Sukkur IBA Journal of Management and Business - SIJMB | Volume 4 No. 2 July - December 2017 @) Sukkur IBA University 
As reported in Table 2, the diagonal values (square root of AVE of the respective constructs) are greater than the other values of the column and the row in which they are situated, confirming the discriminant validity of the outer model (Joseph F Hair et al., 1998).

\subsection{Structural Model}

The results of structural model are presented in Table 3 and Figure 2, below.

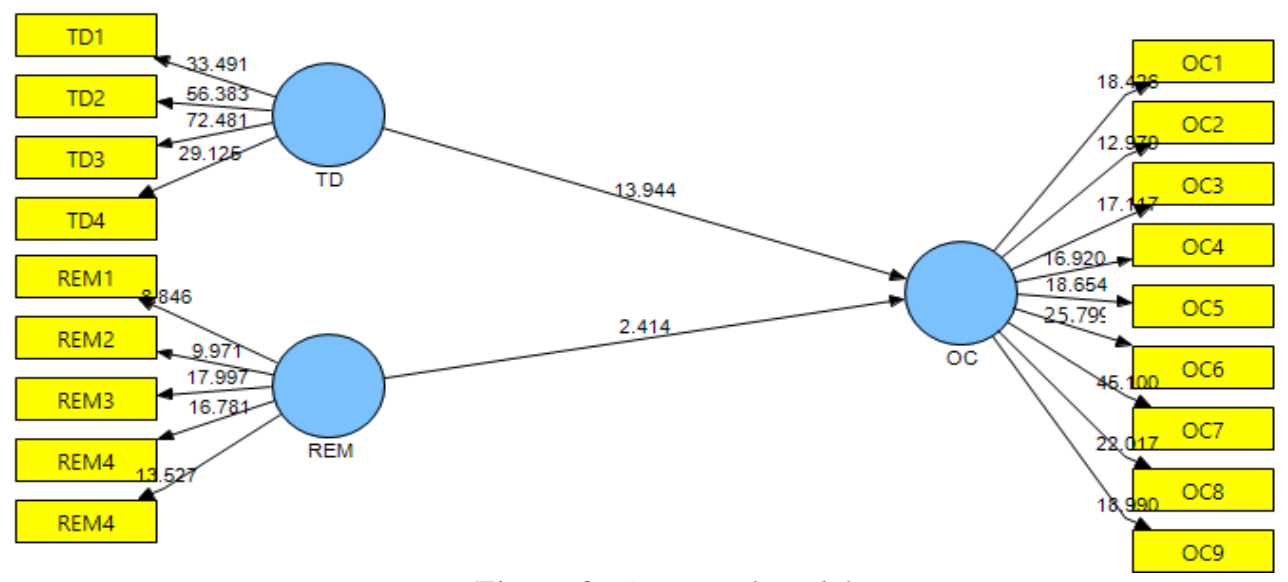

Figure 2: Structural model

Table 3: The result of Structural Model

\begin{tabular}{cccccc}
\hline & $\begin{array}{c}\text { Origina } \\
\mathbf{I} \\
\text { Sample } \\
(\mathbf{O})\end{array}$ & $\begin{array}{c}\text { Standard } \\
\text { Error } \\
(\mathbf{S T E R R})\end{array}$ & $\begin{array}{c}\text { T } \\
\text { Statistics } \\
(\mid \mathbf{O} / \mathbf{S T E R} \\
\mathbf{R} \mid)\end{array}$ & $\begin{array}{l}\text { P- } \\
\text { valu } \\
\text { e }\end{array}$ & $\begin{array}{c}\text { Decisio } \\
\mathbf{n}\end{array}$ \\
\hline $\begin{array}{c}\text { Remuneration } \rightarrow \\
\text { Organizational }\end{array}$ & 0.0954 & 0.0395 & 2.414 & $\begin{array}{r}0.01 * \\
* *\end{array}$ & $\begin{array}{l}\text { Support } \\
\text { ed }\end{array}$ \\
$\begin{array}{c}\text { Commitment } \\
\text { Training and development } \\
\rightarrow \text { Organizational } \\
\text { Commitment }\end{array}$ & 0.577 & 0.0414 & 13.944 & $0.00^{*}$ & $\begin{array}{l}\text { Support } \\
\text { ed }\end{array}$ \\
\hline
\end{tabular}

Note: $* * * p<0.001->$ significant at $0.01(1$ tailed $)$

There is significant relation between remuneration and OC; and T\&D and OC. Table 3 shows that beta $=0.0954, \mathrm{t}$-value $=2.414$ and $\mathrm{p}$-value $<0.01$, suggesting that there is a positive and significant relationship between remuneration and OC. Furthermore, table 3 shows that relationship between $\mathrm{T} \& \mathrm{D}$ and $\mathrm{OC}$ is positive and significant at beta $=0.577, \mathrm{t}$-value $=13.944$ and $\mathrm{p}$-value $<0.00$. Furthermore, the $\mathrm{R}^{2}$ value was 0.35 which suggests that the modelled variables can explain $35 \%$ of the variance of the OC. 


\subsection{Assessment of Effect Size ( $\left.\mathbf{f}^{2}\right)$}

This study assesses effect size for criterion construct. $\mathrm{F}^{2}$ shows the effect of particular criterion variable on predictor construct (Chin et al., 2003). Hence, effect size can be calculated as (Callaghan, Wilson, Ringle, \& Henseler, 2007; Cohen, 1988):

$$
\text { Effect size: } f^{2} \quad=\frac{R_{\text {Included }}^{2}-R^{2} \text { Excluded }}{1-R^{2}{ }_{\text {Included }}}
$$

$\mathrm{R}^{2}$ included and $\mathrm{R}^{2}$ excluded represent $\mathrm{R}^{2}$ value of the exogenous latent variable when selected exogenous variable is included or excluded from the model. Cohen (1988) Suggested that $f^{2}$ value of $0.02,0.15$ and 0.35 as weak, moderate and strong effect respectively. Table 4 shows the calculation and the result of the effect size of each of latent variables.

Table 4: Effect Sizes on Exogenous Construct

\begin{tabular}{lcccc}
\hline & Included & Excluded & f-squared & Effect size \\
\hline R-squared & 0.356 & 0.047 & 0.4798 & Large \\
R-squared & 0.356 & 0.351 & 0.0078 & None \\
\hline
\end{tabular}

As shown in Table 4, the effect size of the exogenous construct (remuneration and T\&D for explaining OC (the endogenous variable) have effect size of 0.479 and 0.007 respectively. Thus, applying the Cohen's (1988) recommendation, the effects sizes of all the exogenous latent variables on $\mathrm{OC}$ can be considered as large and none respectively.

\subsection{Assessment of Predictive Relevance}

After evaluating effect size the current study also assessed predictive relevance technique as suggested by (Joseph F Hair et al., 1998). For this purpose the current study used blindfolding. Similarly, blindfolding method only used for reflected measurement model (Sattler, Völckner, Riediger, \& Ringle, 2010). Thus, in the current study all the endogenous latent variable were reflective. Therefore, blindfolding procedure was used. Similarly, the cross-validated redundancy measure $\left(\mathrm{Q}^{2}\right)$ was used to probe the predictive relevance (Joe F Hair et al., 2011; Henseler \& Chin, 2010). According to Henseler, Ringle, and Sinkovics (2009) have predictive relevance the redundant communality should be higher than zero for endogenous variables.

Table 5: Construct Cross-Validated Redundancy

\begin{tabular}{cccc}
\hline Total & SSO & SSE & 1-SSE/SSO \\
\hline OC & 1980.000 & 1649.589 & 0.167 \\
\hline
\end{tabular}


As shown in Table 5 the cross-validated redundancies for the endogenous variables are 0.167 . This value reveals sufficient predictive capability of the model based on Fornell and Cha (1994) standards which required these values to be larger than zero.

\section{Discussion}

This study aimed to probe the effect of remuneration and T\&D on the OC of academic staff of public HEIs in Pakistan. The outcome of this study validated that there is imperative association between the remuneration and OC. The outcome of this study is also in accordance with previous studies such as (Khan et al., 2013; R. Saeed et al., 2013). This suggests that when academic staff receive adequate remuneration or pay from their institute, there are fair chances that academic staff will show positive behaviour toward organization, be committed and stay longer with the organization. The notion of the social exchange theory (SET) also highlights that when institute provides adequate support for the benefit of the academic staff, they respond in positive feedback toward university (Tansky \& Cohen, 2001).

The outcomes in current study also show imperative association between the T\&D and OC. The outcomes are consistent with the finding of previous research $(\mathrm{K}$. Z. Ahmad \& Bakar, 2003; Al-Emadi \& Marquardt, 2007). This suggests that if employees receive proper training programs from their organization, this may help to improve their skills and cope with new technological change, employees feel that organization cares about them, which leads towards OC. SET also supports the findings, according to which if employees received support from organization in result they feel motivated and it enhances their commitment level toward their organization as stated by (Newman, Thanacoody, \& Hui, 2011).

\subsection{Implications}

The findings of the current study provide empirical evidences theoretically, the correlation among remuneration, $\mathrm{T} \& \mathrm{D}$, and $\mathrm{OC}$. The findings of the current study also add to the literature on remuneration, T\&D and OC. The research findings validate the notion that remuneration and $T \& D$ is contributing significantly by increasing OC among all the academic staff which can lead to practical implication to support the policy makers and practitioners.

There are some implications for HR managers and policy makers of public HEIs of Pakistan based on the above discussion and findings. First, the imperative association between remuneration and $\mathrm{OC}$ concluded that remuneration is one of the vital components in enhancing OC. Remuneration is a very vital aspect of workforce motivation (Chiang \& Birtch, 2010). Therefore, appropriate remuneration can play a vital role to attract and enhance the academic staff commitment level. Second, the imperative correlation between $T \& D$ and $O C$ suggests that $T \& D$ is a significant stable factor in enhancing the OC level among academic staff. The administration of public HEIs needs to assure that there is adequate remuneration and proper training program

Sukkur IBA Journal of Management and Business - SIJMB | Volume 4 No. 2 July - December 2017 @ Sukkur IBA University 
for the employees. The finding forwards view for the organizations to realize the potential of training on organizational commitment and highlights the idea of developing responsive development strategies for employees in this regard.

Present framework of the study is a way forward to the managers related to the needs to enhance the academic staff commitment level. Based on the SET theory, when organizations offer positive HRM practices, employees perceive those practices as the recognition of employees' efforts, and thus they stay for longer period of time with the institution.

In conclusion, it can be argued that the public universities management should pay more attention to proper compensation, and sufficient opportunities for training to increase the academic staff commitment level and retain the potential academic staff and get competitive advantages in the future. In summary, the present study has added valuable theoretical and practical understandings to the growing body of knowledge.

\subsection{Limitations and suggestions for future research}

As this study highlights key factors in enhancing the employee commitment, there are still some limitations. First, the sample in this study only consists of academic staff in KPK, Pakistan. Hence, future research may be expanded to other areas of Pakistan. Second, only the academic staffs were the respondents in this study. The effectiveness of the organization HR practices may be evaluated on the non-academic staff for future research. Investigation into different industries and sectors (e.g. manufacturing sector and services sector) may also be considered to have a more holistic and diverse look at employee commitment.

Third, the present study considered cross sectional approach. However, in future longitudinal research method may be considered to find out the impact of HR practices for the same. Fourth, the present study examines the commitment of academic staff working in public universities. Therefore, future study should consider private universities in the organizational commitment research as may support researchers in future to compare and contrast findings for better statistical understanding.

Finally, present study employs only two HRM practices (i.e. remuneration and T\&D) to study OC. Further study may consider other factors which are known to have an impact on OC such as leadership styles, promotional opportunities, and retention.

\section{References}

Ahmad, A. (2016). Coworker support as moderator on the relationship between HRM practices and Organizational Commitment: A proposed framework. Asian Journal of Multidisciplinary Studies, 4(4).

Ahmad, A., Bibi. P., Khalid, M.M., \& Aziz. (2017). The Impact of HRM Practices on Organizational Effectiveness in Tertiary Institutions. Paper presented at 
the SZABIST's National Research Conference on Management and Business, Islamabad, Pakistan.

Ahmad, A., Majid, A. H. A., \& Zin, M. L. M. (2015). Do compensation and organizational climate affect organizational commitment in higher educational institutions. Paper presented at the International Conference on Entrepreneurship, Business and Social Sciences.

Ahmad, K. Z., \& Bakar, R. A. (2003). The association between training and organizational commitment among white-collar workers in Malaysia. International journal of training and development, 7(3), 166-185.

Al-Emadi, M. A. S., \& Marquardt, M. J. (2007). Relationship between employees' beliefs regarding training benefits and employees' organizational commitment in a petroleum company in the State of Qatar. International journal of training and development, 11(1), 49-70.

Allen, D. G., Shore, L. M., \& Griffeth, R. W. (2003). The role of perceived organizational support and supportive human resource practices in the turnover process. Journal of management, 29(1), 99-118.

Bamberger, P., \& Meshoulam, I. (2000). Human resource management strategy. Published Sage, London, 99.

Becker, B., \& Gerhart, B. (1996). The impact of human resource management on organizational performance: Progress and prospects. Academy of management Journal, 39(4), 779-801.

Bibi, P. (2016). HRM Practices and Empoyees' Rentention: The Job Embeddedness Theory Prospective. Asian Journal of Multidisciplinary Studies, 4(5).

Bibi, P., Pangil, F., Johari, J., \& Ahmad, A. (2017). The Impact of Compensation and Promotional Opportunities on Employee Retention in Academic Institutions: The Moderating Role of Work Environment. International Journal of Economic Perspectives, 11(1), 378-391.

Blau, P. M. (1964). Exchange and power in social life: Transaction Publishers.

Bush, R. F. (2003). Marketing research: online research applications: Prentice-Hall.

Callaghan, W., Wilson, B., Ringle, C. M., \& Henseler, J. (2007). Exploring causal path directionality for a marketing model using Cohen's path method.

Chew, J., \& Chan, C. C. (2008). Human resource practices, organizational commitment and intention to stay. International journal of manpower, 29(6), 503-522.

Chiang, F. F., \& Birtch, T. A. (2010). Pay for performance and work attitudes: The mediating role of employee-organization service value congruence. International Journal of Hospitality Management, 29(4), 632-640.

Chin, W. W., Marcolin, B. L., \& Newsted, P. R. (2003). A partial least squares latent variable modeling approach for measuring interaction effects: Results from a Monte Carlo simulation study and an electronic-mail emotion/adoption study. Information systems research, 14(2), 189-217.

Chughtai, A. A., \& Zafar, S. (2006). Antecedents and consequences of organizational commitment among Pakistani university teachers. 
Chung, E.-C. (2013). The relationship of training and organizational commitment in One Korean organization.

Cohen, J. (1988). Statistical power analysis for the behavioral sciences . Hilsdale. NJ: Lawrence Earlbaum Associates, 2.

Delery, J. E., \& Doty, D. H. (1996). Modes of theorizing in strategic human resource management: Tests of universalistic, contingency, and configurational performance predictions. Academy of management Journal, 39(4), 802-835.

Duarte, P. A. O., \& Raposo, M. L. B. (2010). A PLS model to study brand preference: An application to the mobile phone market Handbook of partial least squares (pp. 449-485): Springer.

Elangovan, A., \& Karakowsky, L. (1999). The role of trainee and environmental factors in transfer of training: An exploratory framework. Leadership \& Organization Development Journal, 20(5), 268-276.

Fornell, C., \& Cha, J. (1994). Partial least squares. Advanced methods of marketing research, 407(3), 52-78.

Gould-Williams, J. S. (1999). The impact of'high performance'HRM practices on employee commitment, service quality and value: a study conducted in the hotel sector. University of Wales. Cardiff.

Hair, J. F., Black, W. C., Babin, B. J., Anderson, R. E., \& Tatham, R. L. (1998). Multivariate data analysis (Vol. 5): Prentice hall Upper Saddle River, NJ.

Hair, J. F., Ringle, C. M., \& Sarstedt, M. (2011). PLS-SEM: Indeed a silver bullet. Journal of Marketing theory and Practice, 19(2), 139-152.

Hair, J. F., Ringle, C. M., \& Sarstedt, M. (2013). Partial least squares structural equation modeling: Rigorous applications, better results and higher acceptance.

Henseler, J., \& Chin, W. W. (2010). A comparison of approaches for the analysis of interaction effects between latent variables using partial least squares path modeling. Structural Equation Modeling, 17(1), 82-109.

Henseler, J., Ringle, C. M., \& Sinkovics, R. R. (2009). The use of partial least squares path modeling in international marketing New challenges to international marketing (pp. 277-319): Emerald Group Publishing Limited.

Huselid, M. A. (1995). The impact of human resource management practices on turnover, productivity, and corporate financial performance. Academy of management Journal, 38(3), 635-672.

Khan, I., Nawaz, A., \& Khan, M. S. (2013). Determining the organizational commitment of academicians in public sector universities of developing countries like Pakistan. International Journal of Academic Research in Accounting, Finance and Management Sciences, 3(1), 280-289.

Lamba, S., \& Choudhary, N. (2013). Impact of HRM practices on organizational commitment of employees. International Journal of Advancements in Research \& Technology, 2(4), 407-423.

Lee, Y.-K., Nam, J.-H., Park, D.-H., \& Ah Lee, K. (2006). What factors influence customer-oriented prosocial behavior of customer-contact employees? Journal of Services Marketing, 20(4), 251-264. 
MacDuffie, J. P. (1995). Human resource bundles and manufacturing performance: Organizational logic and flexible production systems in the world auto industry. ILR Review, 48(2), 197-221.

Malik, M. E., Nawab, S., Naeem, B., \& Danish, R. Q. (2010). Job satisfaction and organizational commitment of university teachers in public sector of Pakistan. International journal of business and management, 5(6), 17.

Mangi, R. A., Soomro, H. J., Ghumro, I. A., Abidi, A. R., \& Jalbani, A. A. (2011). A study of job satisfaction among non Phd faculty in universities.

Mondy, R. (2008). Human Resources Management (1O'h edition): Upper.

Mowday, R. T., Steers, R. M., \& Porter, L. W. (1979). The measurement of organizational commitment. Journal of vocational behavior, 14(2), 224-247.

Nazir, T., Shah, S. F. H., \& Zaman, K. (2012). Literature review on total rewards: An international perspective. African Journal of Business Management, 6(8), 3046.

Nazir, T., Shah, S. F. H., \& Zaman, K. (2014). Review of literature on expatriate compensation and its implication for offshore workforce. Iranian Journal of Management Studies, 7(2), 189.

Newman, A., Thanacoody, R., \& Hui, W. (2011). The impact of employee perceptions of training on organizational commitment and turnover intentions: a study of multinationals in the Chinese service sector. The international journal of human resource management, 22(8), 1765-1787.

Omar, K., Mohamed Anuar, M., Majid, A., Halim, A., \& Johari, H. (2012). Organizational commitment and intention to leave among nurses: the mediating role of moral obligation. International Journal of Management Studies (IJMS), 19(2), 31-46.

Parker, O., \& Wright, L. (2001). PAY AND EMPLOYEE COMMITMENT: THE MISSING LINK-The company that enhances compensation conditions and practices will likely see an improvement in employee commitment. Ivey Business Journal, 65(3), 70-73.

Paul, A., \& Anantharaman, R. (2004). Influence of HRM practices on organizational commitment: A study among software professionals in India. Human Resource Development Quarterly, 15(1), 77-88.

Rasheed, M. I., Aslam, H. D., \& Sarwar, S. (2010). Motivational issues for teachers in higher education: A critical case of IUB. Journal of Management Research, $2(2), 1$.

Riaz, A., Idrees, R. N., \& Imran, A. (2013). Employees' belief regarding training benefits and organizational commitment: a case in banking sector of Pakistan. Middle-East Journal of Scientific Research, 16(3), 310-318.

Robinson, Y. D. (2013). Employee training and organizational commitment in management consulting firms. The George Washington University.

Saeed, M. M., \& Asghar, M. A. (2012). Examining the Relationship between Training, Motivation and Employees Job Performance-The Moderating Role of Person Job Fit. Journal of Basic and Applied Scientific Research, 2(12), 12177-12183. 
Saeed, R., Nayyab, H. H., Lodhi, R. N., Baqir, R., Rehman, M. A., \& Mussawar, S. (2013). Impact of retention factors on organizational commitment in general education division of Pakistan. Middle-East Journal of Scientific Research, 17(4), 539-545.

Sattler, H., Völckner, F., Riediger, C., \& Ringle, C. M. (2010). The impact of brand extension success drivers on brand extension price premiums. International Journal of Research in Marketing, 27(4), 319-328.

Schuler, R. S., \& MacMillan, I. C. (1984). Gaining competitive advantage through human resource management practices. Human Resource Management, 23(3), 241-255

Shaheen, I., Sajid, M., \& Batool, Q. (2013). Factors affecting the motivation of academic staff (a case study of University College Kotli, UAJ\&K). International Journal of Business and Management Invention, 2(1), 105-112.

Sial, M. A., Jilani, S. M. A., Imran, R., \& Zaheer, A. (2011). Effect of human resource practices on organizational commitment in Pakistani universities. World Applied Sciences Journal, 15(6), 793-798.

Tansky, J. W., \& Cohen, D. J. (2001). The relationship between organizational support, employee development, and organizational commitment: An empirical study. Human Resource Development Quarterly, 12(3), 285-300.

Teclemichael Tessema, M., \& Soeters, J. L. (2006). Challenges and prospects of HRM in developing countries: testing the HRM-performance link in the Eritrean civil service. The international journal of human resource management, 17(1), 86105.

Tsai, W.-C., \& Tai, W.-T. (2003). Perceived importance as a mediator of the relationship between training assignment and training motivation. Personnel review, 32(2), 151-163.

Wold, H. (1974). Causal flows with latent variables: partings of the ways in the light of NIPALS modelling. European Economic Review, 5(1), 67-86. 